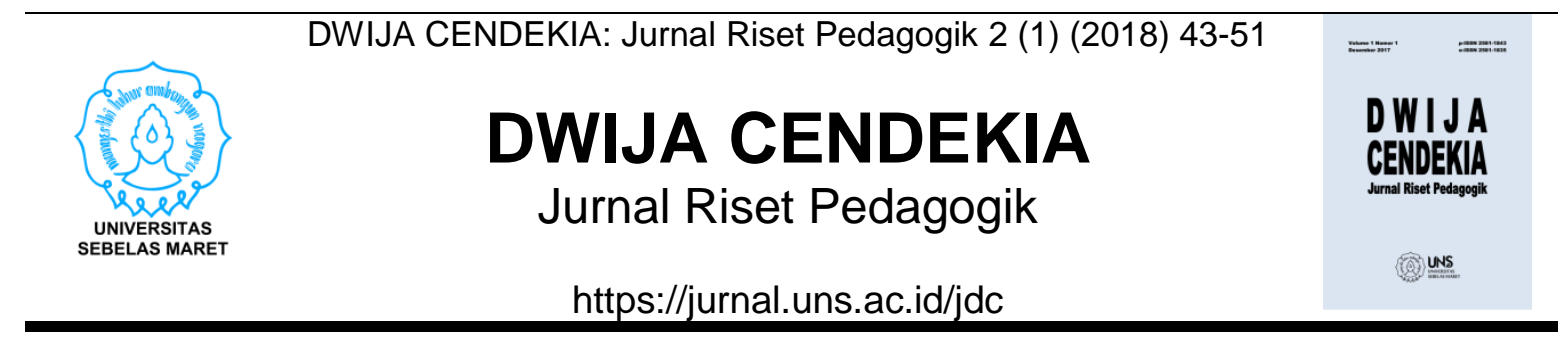

\title{
"GEOPARK CILETUH" CULTUREDIVERSITY (ETNOLITERASI BERBASIS BUDAYA DAN PARIWISATA) SEBAGAI MEDIA DAN SUMBER PEMBELAJARAN IPS DI SD
}

\section{Rohmat Widiyanto', Saprudin², Aritsya Imswatama}

${ }^{1}$ UIN Syarif Hidayatullah, ${ }^{2,3}$ Universitas Muhammadiyah Sukabumi

\section{Sejarah Artikel}

Diterima 1 Februari 2018

Disetujui 22 Mei 2018

Diterbitkan 1 Agustus 2018

\section{Kata Kunci}

etnoliterasil

culturediversity, media,

sumber belajar.

\begin{abstract}
Abstrak
Penelitian ini bertujuan untuk mengidetifikasi dan melestarikan budaya (kearifal lokal, cerita, komoditi unggulan) dan pariwisata yang berdata di kawasan Geopark Ciletuh desa Tamanjaya kecamatan Ciemas kabupen Sukabumi Jawa Barat. Selain itu, penelitian Potensi alam dan kebudayaan tersebut tentunya dapat dijadikan sebagai media dan sumber belajar dalam pembelaajaran IPS SD sebab keragaman culturediverdity dan biodiversity yang ada. Pendekatan penelitian ini menggunakan motode penelitian Kualitatif deskriftif. Penelitian kualitatif deskriptif merupakan penelitian yang mendeskripsikan atau mengambarkan fenomena yang ada, baik fenomena yang bersifat alamiah ataupun rekayasa manusia. Hasil penelitian ini sebagai berikut: di desa Tamanjaya terdapat etnoliterasi berupa bangunan adat, kepercayaan dan komoditi tanaman. Dari bagunan adat daerah Taman jaya dan Ciwaru memiliki kesamaan bangunan yakni rumah pangung, tagok anjing dan leuit. Sedangkan untuk petilasan terdapat petilasan mbah Durak (Dusun Cikalong), Mbah Bugis (Pulau Mandra), Mbah Lamping (Girimukti). Adapun tanaman endemik Tamanjaya beras hitam, Loa, Malaka. Sedangkan Ciwaru haur gerem, Beriueh taman yang hidup dengan tinggi hampir $100 \mathrm{~m}$ dan Kepuh.

\section{Cara Mengutip}

Widiyanto, R., Saprudin, Imswatama, A. (2018).

"Geoparkciletuh" Culturediversity (Etnoliterasi Berbasis Budaya dan Pariwisata) Sebagai Media dan Sumber Pembelajaran IPS di SD. DWIJA CENDEKIA: Jurnal Riset Pedagogik, 2 (1), 43-51
\end{abstract}

Korespondensi Penulis

rohmat.widiyanto@uinjkt.ac.id
p-ISSN 2581-1843

e-ISSN 2581-1835 


\section{PENDAHULUAN}

Geopark Ciletuh merupakan salah satu wilayah yang direncanakan menjadi Goepark oleh united nations educational, scientific, and cultural organization (UNESCO). Geopark Ciletuh terletak di kecamatan Ciemas kabupaten Sukabumi, dan salah satunya terdapat di desa Tamajaya. Desa Tamajaya merupakan desa yang mempunyai potensi alam dan kebuadayaan yang masih khas. Potensi alam tersebut meliputi beberapa tempat yang dijadikan objek wisata. Selain itu desa Tamanjaya juga terdapat beberapa taman langka dan khas lokal yang dapat dikembangkan menjadi komoditi unggulan.

Keadaan yang demikian dapat dimanfaatkan oleh masyarakat setempat sebagai salah satu cara untuk meningkatkan perekonomian daerah tersebut, dengan berbagai usaha misalnya UMKM, back packer, industri kreatif, pariwisata dan lain sebagainya, apalagi jika kawasan desa Tamanjaya dijadikan sebagai Geopark oleh UNESCO.

Namun, pada saat ini ada beberapa masalah yang krusial tidak disadari oleh pada masyarakat umumnya. Misalnya belum adanya pemetaan dan identifikasi budaya maupun kearifan lokal yang dimiliki oleh desa/wilayah, kurangnya andil masyarakat dalam publikasi dan pelestarian Geopark Ciletuh serta mengenai sejarah tentang wisatawisata di desa Tamanjaya.

Penelitian ini bertujuan untuk mengidetifikasi dan melestarikan budaya (kearifal lokal, cerita, komoditi unggulan) dan pariwisata yang berdata di kawasan Geopark Ciletuh desa Tamanjaya kecamatan Ciemas kabupen Sukabumi Jawa Barat. Selain itu, penelitian Potensi alam dan kebudayaan tersebut tentunya dapat dijadikan sebagai media dan sumber belajar dalam pembelaajaran IPS SD sebab keragaman culturediverdity dan biodiversity yang ada.

Keragaman Culturediversity/budaya dan biodiversity/hayati yang di tawarkan oleh wilayah Ciemas Geopark meliputi rumah adat, tarian khas wilayah, kekayaan tradisional, keragaman biota pantai, keragaman flora dan fauna nampaknya menjadi hoptesis awal peneliti dalam kajian pemamfaatannya sebagai sumber dan media pembelajaran IPS SD yang kajiannya mecakup; 1) konsep manusia, linkungan dan sumber daya alam, 2) konsep waktu keberlanjutan dan perubahan, 3) konsep sistem sosial budaya, ekonomi dan kesejahteraan.

\section{METODE PENELITIAN}

\begin{abstract}
Penelitian ini menggunakan metode deskriptif. Penelitian inimendeskripsikan dan mengidentifikasi tentang budaya (kearifan lokal, cerita, komoditi uggulan) dan pariwisata. Penelitian ini akan dilaksanakan di desa Tamanjaya dan desa Ciwaru Kecamatan Ciemas Kabupaten Sukabumi. Perangkat instrumen ini berupa lembar wawancara, observasi dan dokumentasi. Teknik
\end{abstract}

analisis data yang digunakan dalam penelitian ini adalah menggunakan langkah-langkah seperti yang dikemukakan oleh Levi's Straus dalam Bungin (2003:70),pengumpulan data, reduksi data, display data, verifikasi dan penegasan kesimpulan. 


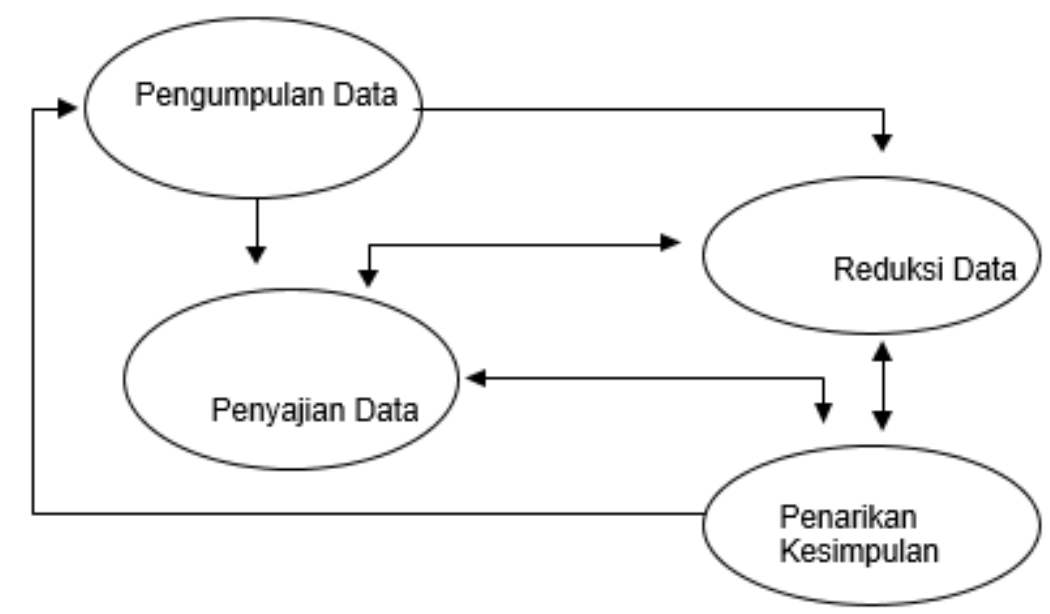

\section{Gambar 1. Alur dan Tahun Penelitian Interaktif Miles \& Huberman dalam}

\section{PEMBAHASAN}

Berdasarkan hasil informasi yang didapat mengenai wilayah Desa Ciwaru secara administratif berada di wilayah Kecamatan Ciemas Kabupaten Sukabumi dengan batas wilayah desa sesuai gambar 2.

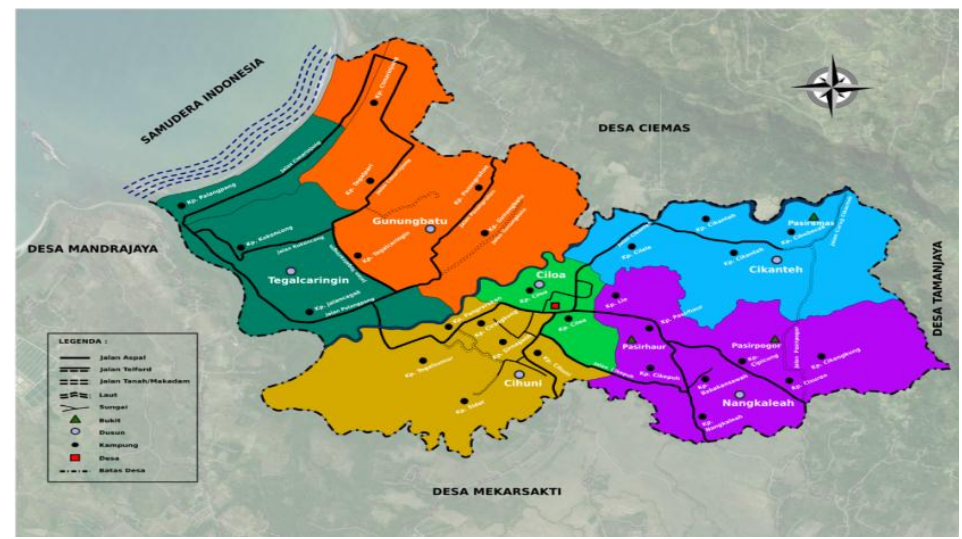

\section{Gambar 2. Wilayah Desa Ciwaru}

Berdasarkan gambar 2, batas wilayah deay meliputi;

1. Sebelah Utara berbatasan dengan Desa Ciemas.

2. Sebelah Timur berbatasan dengan Desa Tamanjaya dan Desa Mekarsakti.

3. Sebelah Selatan berbatasan dengan Desa Mekarsakti dan Desa Mandrajaya.
4. Sebelah Barat berbatasan dengan Samudera Indonesia.

Desa Ciwaru berada pada ketinggian 0-100 meter di atas permukaan air laut, topografi wilayahnya $70 \%$ datar dan $30 \%$ bergelombang, jenis tanah Latosol seluas $100 \%$. Jenis tanah tersebut mempunyai sifat fisik dan kimia serta mempunyai tingkat kesuburan yang cukup tinggi.

Temperatur udara minimal $21^{\circ} \mathrm{C}$ dan maksimal $25^{\circ} \mathrm{C}$. Ph tanah antara 4.5 - 
6.5 , curah hujan rata-rata selama 5 tahun terakhir sebanyak $3.613 \mathrm{~mm}$ setiap tahun. Luas wilayah desa Ciwaru seluruhnya $955.89 \mathrm{Ha}$, yang terdiri atas lahan sawah seluas $463.69 \mathrm{Ha}$ dan darat seluas $492.20 \mathrm{Ha}$. Lahan Sawah terdiri dari Sawah Irigasi Teknis $392.69 \mathrm{Ha}$, Sawah Irigasi $1 / 2$ Teknis 46 Ha dan Sawah Tadah Hujan $25 \mathrm{Ha}$. Sedangkan pada lahan darat terdiri dari tegal/ladang seluas $100.51 \mathrm{Ha}$, Pemukiman $285.65 \mathrm{Ha}$, Pekarangan $65.87 \mathrm{Ha}$, Taman $6.40 \mathrm{Ha}$, Perkantoran $2.30 \mathrm{Ha}$, Kuburan 6.47, dan Prasarana Umum lainnya $25 \mathrm{Ha}$. Rincian penggunaan tanah pada pelbagai lahan disajikan pada Tabel 1.

Tabel 1. Luas Lahan Menurut Penggunaannya di Desa Ciwaru Tahun 2015

\begin{tabular}{|c|c|c|c|}
\hline No & Penggunaan Lahan & Luas $(\mathrm{Ha})$ & Persentase \\
\hline \multirow[t]{4}{*}{1.} & \multicolumn{3}{|l|}{ Sawah } \\
\hline & 1. Irigasi Teknis & 438.69 & 95 \\
\hline & 2. Tadah Hujan & 25 & 5 \\
\hline & Jumlah & 463.69 & 100 \\
\hline \multirow[t]{8}{*}{2.} & \multicolumn{3}{|l|}{ Lahan Darat } \\
\hline & 1. Tegal/Ladang & 100.51 & 20 \\
\hline & 2. Pemukiman & 285.65 & 58 \\
\hline & 3. Pekarangan & 65.87 & 13 \\
\hline & 4. Taman & 6.40 & 1.5 \\
\hline & 5. Perkantoran & 2.30 & 0.5 \\
\hline & 6. Kuburan & 6.47 & 1.5 \\
\hline & $\begin{array}{l}\text { 7. Prasarana } \\
\text { lainnya }\end{array}$ & 25 & 5 \\
\hline \multicolumn{2}{|c|}{ Jumlah } & 492.20 & 100 \\
\hline \multicolumn{2}{|c|}{ Total Luas Sawah dan Darat } & 955.89 & 100 \\
\hline
\end{tabular}

Sumber: Profil Desa tahun 2015

Berdasarkan pada hasil pengumpulan data berhubungan dengan kearifan budaya lokal, desa Ciwaru masih kental dengan kepercayaan-kepercayaan nenek moyang seperti, masih mempercayai peringatan 40 hari jika sanak sodaranya ada yang meninggal, biasanya dalam acara tersebut diadakan pengajian dan melakukan ziarah keesokan harinya. Bagi keluarga yang ditinggalkan namun memiliki rizeki lebih, setelah pengajian selesai maka setiap tamu yang hadir akan diberikan amplop dan makanan, baik berupa makanan berat maupun sembako.

Kearifan budaya lokal lainnya yang masih diperingati di desa Ciwaru yaitu acara peringatan masa penutupan nifas bagi lbu yang baru melahirkan (40 hari). Acara tersebut bertujuan untuk membersihkan diri dari hadas besar.
Kegiatan ini berupa siraman dan membacakan doa-doa nifas oleh emak paraji. Selain acara siraman, dengan waktu yang sama diadakannya gunting rambut bagi bayi yang berumur 40 hari. Rambut bayi yang telah digunting dikumpulkan untuk ditimbang dan diberi harga. Setelah mengetahui jumlah timbangan rambut bayi, maka rambut diuangkan sesuai dengan harga emas. Uang tersebut diberikan kepada orang yang kurang mampu, mereka percaya bahwa dengan melakukan hal tersebut kelak bayi akan terbiasa untuk bersodaqoh.

Di samping itu, kami membuat artikel mengenai sejarah pasar minggu yang biasa diadakan diakhir pekan mulai pukul 13.00 sampai pukul 21.00 WIB. Adapun budaya yang masih dipercaya dan diyakini adalah peringatan hari 
nelayan yang diperingati setiap satu Juni tahun sekali pada bulan Mei atau bulan

Tabel 2. Hasil Indentifikasi Etnoliterasi Budaya Desa

\begin{tabular}{|c|c|c|c|}
\hline No & $\begin{array}{lll}\text { Etnoliterasi } & \text { Budaya dan } \\
\text { Pariwisata } & & \\
\end{array}$ & Budaya/Edukasi & Pariwisata \\
\hline 1. & Peringatan 40 hari & $\begin{array}{l}\text { Makna sesunguhnya } \\
\text { adalah silaturahmi }\end{array}$ & $\begin{array}{l}\text { Perayaan } \\
\text { adat }\end{array}$ \\
\hline 2. & Siraman Nifas & $\begin{array}{l}\text { Makna sesunguhnya } \\
\text { adalah berbagi }\end{array}$ & $\begin{array}{l}\text { Perayaan } \\
\text { adat }\end{array}$ \\
\hline 3. & Peringatan Hari Nelayan & $\begin{array}{l}\text { Makna sesunguhnya } \\
\text { adalah berbagi }\end{array}$ & $\begin{array}{l}\text { Perayaan } \\
\text { adat }\end{array}$ \\
\hline 4. & Rumah Tagok Anjing & $\begin{array}{l}\text { Berbentuk limas dengan } \\
\text { diameter } \quad \text { matematis } \\
\text { mengurangi hempasan } \\
\text { angin. }\end{array}$ & $\begin{array}{l}\text { Nilai sejarah } \\
\text { bangunan dan nilai } \\
\text { edukasi matematis }\end{array}$ \\
\hline
\end{tabular}

Desa Tamanjaya Kecamatan Ciemas Kabupaten Sukabumi, terletak di ibu kota Kecamatan Ciemas dengan ketinggian rata-rata $400 \mathrm{M}$ di atas permukaan laut dengan geografis terbagi dua wilayah dataran yaitu wilayah dataran rendah dan wilayah dataran tinggi yang memiliki luas wilayah 1.372,5 $(\mathrm{Ha})$ terdiri dari:

a. Tanah sawah seluas : $425 \mathrm{Ha}$

b. Tanah darat seluas : $950,5 \mathrm{Ha}$

Dengan jumlah penduduk JiwaLaki-laki
a. Perempuan
b. KK
c. Rumah
Rumah

\section{A. Peta dan Kondisi Umum Desa}

Utara : Berbatasan dengan Desa Mekarjaya.

Timur: Berbatasan dengan Desa Caringinunggal Kec. Waluran yang dibatasi sungai Ciletuh.

Selatan : Berbatasan dengan Desa Cibenda yang dibatasi Sungai

Ciletuh dan Desa Mekarsakti yang dibatasi Sungai Cikalong.

Barat : Berbatasan dengan Desa

Ciwaru yang dibatasi Kali

Cisuren.

B. Jarak dari pusat pemerintahan

Dari ibu kota Negara

Dari ibu kota Provinsi

: $225 \mathrm{Km}$

: $216 \mathrm{Km}$
Dari ibu kota Kabupaten $\quad: 60,5 \mathrm{Km}$ Dari ibu kota Kecamatan : $0,5 \mathrm{Km}$ Berdasarkan pada hasil identifikasi nilai etnoliterasi desa Tamanjaya memiliki nilai budaya dan pariwisata sebagai berikut;

1. Budaya Rumah Adat Tagok Anjing, Lueit dan rumah pangung

Salah satu aspek yang menunjang dalam perwujudan konsep geopark adalah budaya. Keberadaan kebudayaan di desa Tamanjaya salah satunya yang masih dipertahankan adalah rumah adat Sunda. Walaupun memang keberadaanya seiring dengan perkembangan zaman kian tergerus oleh pemahaman penduduknya yang lebih memilih merubah rumahnya menjadi rumah modern. Oleh karna itu mahasiswa melakuakan pengkajian mengenai rumah adat sunda yang dimana itu akan menjadi aspek penting terwujudnya konsep geopark.. Adapun yang menjadi narasumber dalam pengkajian ini adalah Cecep Nurdin dan Mbah Dini, sesepuh Tamanjaya yang masih mempertahankan Rumah Adat khas Sunda.

Berdasarkan pemaparan dari Cecep Nurdin bahwa asal muasal dari kebudayaan Sunda, termasuk rumah adat adalah kerajaan Padjajaran, yaitu pada masa kerajaan Prabu Siliwangi. 
Rumah sendiri merupakan salah satu tempat suatu kelompok atau keluarga bertempat tingal dengan fungsinnya rumah sebagai tempat berlindung. Dalam adat Sunda rumah juga mempunyai syarat atau ketentuan berlaku sebelum berdirinya bangunan atau pondasi, khususnya rumah yang ada di Desa Tamanjaya, Kec. Ciemas, Sukabumi. Dengan kentalnya budaya serta adat yang masih digunakan bahkan dilestarikan merupakan salah satuidentitas kelompok suatu daerah. Rumah adat yang ada di Desa Tamanjaya Kec. Ciemas adalah Rumah yang berbentuk panggung yang terbuat dari material bambu, karena bahan dari bambu mempunyai kapasitas dan kualitas bagus untuk digunakan dalam pembuatan rumah panggung yang ada di Desa Tamanjaya, bambu yang digunakan adalah jenis bambu Luwi. Disamping itu syarat yang penuh akan budaya dan ritual membuat pembagunan rumah ini mempunyai beberapa tahap dan perhitungan menurut kepercayaan dan anutan warga Desa Tamanjaya.

Dalam proses pembuatan rumah panggung di Desa Tamanjaya, ada beberapa langkah dan perhitungan dalam menentukan posisi, tempat dan arah yang harus diperhitungkan sebelumnya secara matang dan tepat, berikut adalah beberapa tahap dan syarat yang didapat dari hasil wawancara kami dengan salah satu warga Desa Tamanjaya :

2. Tong Gagabah, artinya dalam kepercayaan masyarakat Desa Tamanjaya ada kepercayaan bahwa, setiap tempat ada penghuninya yang tidak terlihat oleh kasat mata, oleh karena itu, diharuskan kepada masyarakat yang akan membangun rumah panggung untuk sadar dan tidak semena-mena dalam proses sebelum dan sesudah pembangunan rumah.

3. Kudu Bersih, artinya penghuni rumah harus memperhatikan kebersihan lingkungan rumah bahkan seisi rumahnya, dan juga untuk kenyamanan penguhuni rumah.
4. Ulah jail, artinya adanya batasan perilaku penghuni rumah agar memperhatikan beberapa aturan adat yang berlaku untuk keselamatan serta kenyamanan penghuni rumah.

Setelah terpenuhinya syarat di atas maka barulah bisa ditentukan dari hari lahir penghuni rumah, dan berikut adalah penentuan hari menurut perhitungan kepercayaan mereka :

a. Senin dan Selasa rumah diharuskan menghadap ke Wetan Kaler

b. Rabu diharuskan menghadap ke Ngidul Kulon

c. Kamis diharuskan menghadap ke Ngaler ngetan

d. Jumat diharuskan menghadap ke Ngidul ngetan

e. Sabtu diharuskan menghadap ke Ngulon ngidul

f. Minggu diharuskan menghadap ke Ngu lon ngidul

Dari beberapa ketentuan diatas adanya larangan yang berlaku menurut makna jari tangan, yaitu :

a. Ibu jari (sri) Sri sering juga dikaitkan dengan dewi padi dalam budaya sunda, yaitu Dewi Sri atau Nyi Pohaci. Jadi dapat pula dimaknai dengan banyaknya pangan yang kita dapat. Sri bermakna baik dalam hitungan ini, dapat pula diartikan rezeki yang melimpah.

b. Telunjuk (Lungguh) Lungguh sering dikaitkan dengan derajat, pangkat, jabatan, kekuatan, dan kemampuan. Lungguh bermakna baik dalam hitungan ini.

c. Jari tengah (dunya) Dunya sering dikaitkan dengan harta, rezeki, materi, dan kekayaan yang melimpah ruah. Hitungan ini biasanya paling dicari dalam setiap hajat atau suatu hal yang membutuhkan perhitungan.

d. Jari manis (rara) Lara sering dikaitkan dengan sesuatu penderitaan atau sakit, baik 
dari segi kesehatan, ketenangan lahir atau pun batin. Hitungan ini biasanya dihindari dalam setiap hajat atau suatu hal yang membutuhkan perhitungan.

e. Kelingking (pati) Pati berarti mati. Namun tidak dengan serta merta kita mengaitkannya dengan kematian. mati disini dapat berarti mati secara rezeki, mati dalam arti perceraian, mati dalam arti hal-hal yang bersifat paling buruk. Hitungan ini biasanya paling dihindari dalam setiap hajat atau suatu hal yang membutuhkan perhitungan.

\section{Wisata Petilasan dan Cerita Rakyat}

Berdasarkan pemaparan narasumber dan hasil dokumentasi beberapa macam budaya religi adalah sebagai berikut; petilasan mbah Durak (Dusun Cikalong), Mbah Bugis (Pulau Mandra), Mbah Lamping (Girimukti) semua petilasan tersebut terletak di kecamatan Ciemas.

Misalnya kearifan lokal yang dapat dijadikan sebagai suatu bentuk nilai dan kepercayaan di masyarakat adalah leluhur. Misal salah satunya, makam Eyang Suraninamg terletak di sebelah utara desa Tamanjaya, dusun Cicurug, tepat 10 meter di samping kiri jalan desa menuju ke Mekarjaya. Makam tersebut memiliki luas sekitar $5 \times 3 \mathrm{~m} 2$, setiap sudut dari makam tersebut dibatasi oleh daun Kibling, dan di tengah makam tersebut terdapat batuan berbentuk persegi panjang berukuran sekitar $97 \mathrm{~cm}$ sebanyak dua buah yang diletakan disamping kiri dan kanan nisan makam, juga terdapat bata yang mengelilingi batu tersebut. Batuan tersebut sangat mirip dengan batuan yang ada di situs Megalitikum Gunung Padang, Cianjur.
Sedangkan untuk nisannya, berdasarkan keterangan Dr. Saprudin, bahwa nisan tersebut memiliki kesamaan dengan bentuk nisan kuningan, yakni membentuk tubuh manusia yang terdiri dari kepala, tangan, dan badan. Disisi sebelah barat makam Eyang Suranimang, tepat berdampingan makam seorang anak kecil. Berdasarkan informasi makam itu adalah makam seorang anak yang tidak mempunyai lengan.

Berdasarkan pemaparan oleh Mbah Ubed, bahwa Eyang Suranimang berasal dari Kuningan yang kemudian hijrah ke Banten. Asal muasal Eyang Suranimang ke Cirameng (sekarang Tamanjaya), yakni karna pada saat beliau ada di Banten terjadi kemelut perang maka beliau memutuskan untuk hijrah ke Tamanjaya, Sukabumi. Di Tamanjaya beliau membentuk sebuah pertahanan untuk menghalau penjajah.

Pada masanya, Eyang

Suranimang diangap oleh masyarakat Tamanjaya sebagai sosok yang mampu dan bijaksana dalam memberikan pertimbangan terhadap setiap permasalahan, seperti meminta pertimbangan terkait masalah waktu penanaman padi, pekerjaan, atau lain sebagainya.Nama Suranimang itu sendiri berasal dari kata Nimbang yang artinya memberikan keputusan, namun belum diketahui bahwa Suranimang itu nama asli dari Eyang Suranimang ataukah nama gelar yang diberikan masyarakat. Selain dari pada itu Eyang Suranimang diklaim pernah memprediski bahwa bahwa kelak nanti dimasa depan kawasan daerah Ciemas khususnya Cikalong akan menjadi daerah yang maju karna memiliki potensi alam yang luar biasa, lebih lanjut lagi, beliau mengatakan bahwa kelak akan ada jalan kereta api yang akan menjadi akses menuju Ciemas dari Ujung Pandang. 
Tabel 3. Hasil pemetaan desa Taman Jaya

\begin{tabular}{|c|c|c|c|}
\hline No & $\begin{array}{c}\text { Etnoliterasi Budaya dan } \\
\text { Pariwisata }\end{array}$ & Budaya/Edukasi & Pariwisata \\
\hline 1. & $\begin{array}{l}\text { Rumah adat, Luewit, Tagok } \\
\text { Anjing }\end{array}$ & $\begin{array}{l}\text { Secara kajian } \\
\text { matematis memiliki } \\
\text { kesebangunan, } \\
\text { arah angina dan } \\
\text { kekuatan bangunan }\end{array}$ & Bagunan adat \\
\hline 2. & $\begin{array}{l}\text { Petilasan, petilasan mbah } \\
\text { Durak (Dusun Cikalong), Mbah } \\
\text { Bugis (Pulau Mandra), Mbah } \\
\text { Lamping (Girimukti) }\end{array}$ & $\begin{array}{l}\text { Petilasan lama, } \\
\text { mengedukasi } \\
\text { jangan sampai } \\
\text { budaya animism } \\
\text { dan dinamisme } \\
\text { muncul kembali } \\
\text { sebagai kemusrikan } \\
\text { di masyarakat. }\end{array}$ & Petilasan \\
\hline
\end{tabular}

\section{SIMPULAN}

Etnografi desa Ciwaru dan Tamanjaya dapat di tinjau berdasarkan beberapa kajian berikut;

1. Budaya Religi

Berdasarkan pemaparan narasumber dan hasil dokumentasi beberapa macam budaya religi adalah sebagai berikut; petilasan mbah Durak (Dusun Cikalong), Mbah Bugis (Pulau Mandra), Mbah Lamping (Girimukti) semua petilasan tersebut terletak di kecamatan Ciemas.

2. Budaya Keseniaan

Beberapa hasil kebudayaan yang ditemukan didesa Taman Jaya dan Ciwaru; Silat (Tamanjaya) Lais \& Buncis (Tamanjaya), Gondagan (Ciwaru), syukuran neelayan, Sabrud (Cerita Komedi/bobodoran), Cepet (Ciwaru).

3. Budaya Bangunan
Budaya rumah adat terdiri dari rumah pangung tagog anjing dan Leuit adalah lumbung padi masyaratakat Tamanjaya dan Ciwaru.

4. Budaya Endemik Tamanan

Adapun tamanan endemik Tamanjaya Beras Hitam, Loa, Malaka. Adapun Ciwaru haur gerem adapun cirinya pohon berduri, berfungsi meruncingkan cula badak dan penyelamatan ayam hutan dari perburuan liar. Beriueh taman yang hidup dengan tinggi hamper $100 \mathrm{~m}$ dan diameter $15 \mathrm{~m}$ berfungsi sebagai tempat tinggal lebah madu hutan. Kepuh digunakan untuk bahan bangunan yang sangat baik

\section{DAFTAR PUSTAKA}

Abdurrahman, O. (2014). Keragaman Bumi Ciletuh-Jampang. Bandung: Badan Geologi Unpad.

Arikunto, S. (2003). Manajemen Penelitian. Jakarta: PT. Rineka Cipta.
Bungin, B. (2003). Analisis data penelitian kualitatif, pemahaman filosofis dan metodologis ke arah penguasaan model aplikasi. Jakarta: PT. Raja Grafindo Persada.

Budiyono. (1998). Metodologi Penelitian Pengajaran Matematika. Surakarta: UNS Press. 
R. Widiyanto, dkk /DWIJA CENDEKIA: Jurnal Riset Pedagogik 2 (1) (2018) 43-51

Kanisius, S., K. (2014). Filsafat Lingkungan Hidup, Alam sebagai Sebuah Sistem Kehidupan. Jakarta: Rineka Cipta.

Mc.Kenna \& Robinson. (2010). Identification aktiviti and literace. New Jersey: Routledge.

Miyaki, Foster, Bellamy, J. (2013). Ekologi Marx; Materialisme dan Alam, terj. Pius Ginting, Jakarta: Walhi.

Pendit, R., S. (2012). Pengantar Pedagogik Transformatif. Jakarta. UHAMKA PRESS.
Sukmadinata, N.S (2008). Metode Penelitian Pendidikan. Bandung: PT. Remaja Rosdakarya.

Subadriyah, dkk (2013). Pembelajaaran Literasi. Bandung: Alfabeta

Yoeti, O. A. (1995) Pengantar IImu Pariwisata, Jakarta : Angkasa.

Saprudin, dkk. (2015). Pedoman Kuliah Kerja Nyata (KKN) Tematik Universitas Muhammdiyah Sukabumi. Sukabumi: UMMIPRESS Kampus Universitas Muhammadiyah Sukabumi 